\title{
THE TRANSFORMATION OF REFORMED NATURAL LAW DOCTRINE IN SAMUEL RUTHERFORD'S LEX, REX
}

Author:

Andries Raath ${ }^{1}$

\section{Affiliation:}

${ }^{1}$ Research Fellow, Department of History, University of the Free

State,Bloemfontein

Correspondence to: Andries Raath

Email:

RaathA@ufs.ac.za

Dates:

15 Dec 2015

How to cite this article: Raath, A., 2015. "The transformation of Reformed natural law doctrine in

Samuel Rutherford's Lex, Rex". KOERS - Bulletin for Christian Scholarship, 80(4). Available at: http:// dx.doi.org/10.19108/

koers.80.4.2245

\section{Copyright:}

(C) 2015. The Author(s)

Published under the

Creative Commons

Atribution License.
In addition to Rutherford's emphasis on core ideas of Reformed thought concerning God's ordination of civil government for His glory and equating divine law with natural law, he grounds both natural law and the limits to political authority in a covenant of creation between God and man. Flowing from these ideas, Rutherford distinguishes between the institution of the office (political government), and the designation of a person or persons to the office. A most important perspective emanating from Rutherford's covenantal natural law theory is his distinction between ends and means on secondary causation in the subject's involvement in political life. This essay investigates some of the implications flowing from Rutherford's transformation of Reformed natural law doctrine.

Key terms: covenant, Lex, Rex, natural law, political government, Samuel Rutherford

Bykomend tot Rutherford se beklemtoning van fundamentele idees van die Reformatoriese denke met betrekking tot God se instelling van burgerlike regering tot sy eer en die vereenselwiging van goddelike reg met natuurreg, grond hy sowel die natuurreg as die perke van politieke gesag in 'n skeppingsverbond tussen God en die mens. Uit hierdie opvattings spruit Rutherford se onderskeid tussen die instelling van die owerheidsamp (politieke regering) en die aanwysing van ' $n$ persoon of persone in sodanige ampte. 'n Uiters belangrike perspektief wat spruit uit Rutherford se verbondsmatige natuurregsteorie is sy onderskeid tussen doelwitte en middele met betrekking tot sekondêre oorsaaklikheid in die onderdaan se betrokkenheid in die politieke lewe. Hierdie artikel ondersoek sommige van die implikasies van Rutherford se transformasie van die Reformatoriese natuurreg-leerstuk.

Sleutelterme: Lex, Rex, natuurreg, politieke regering, Samuel Rutherford, verbond 


\section{INTRODUCTION}

The polemical treatise Lex, Rex (1644) by Samuel Rutherford, in reply to the royalist assertions by John Maxwell, Bishop of Ross, in his Sacro-sancta regum majestas (1644), represents a major development in reformed political thought up to that time. It is a long and detailed work of political theory in justification of the Puritan views on law and government. Although primarily aimed at refuting the arguments of English and Scottish royalist writers, this work proved to be a most influential compendium of the core ideas of Reformed politics of the sixteenth and seventeenth centuries.

In addition to Rutherford's emphasis on principles of Reformed thought concerning God's ordination of civil government for His glory and equating divine law with natural law, he grounded both natural law and the limits to political authority in a covenant of creation between God and man. Flowing from these ideas, Rutherford distinguished between the institution of the office (political government), and the designation of a person or persons to the office. A most important view emanating from Rutherford's covenantal natural law theory is his distinction between ends and means, and secondary causation in political life. Describing the concept of civil government as founded by God and practised by men, Rutherford describes the nature of this ordinance with particular reference to monarchy. $\mathrm{He}$ regards the power of monarchy to be derivative from God, while its effectual establishment comes from the people: "The question is, Whether the kingly office itself come from God. I conceive it is, and floweth from the people ... God ordained the power. It is from the people only by a virtual emanation, in respect that a community having no government at all may ordain a ruler or appoint an aristocracy" (LR, Q 4: 6). ${ }^{1}$ By advancing the idea that government exists only through the consent of the community, Rutherford's covenantal natural law theory not only postulates the ground ideas of Reformed democracy, but also provides for circumstances and conditions under which the subjects may resist civil government, and, in extreme circumstances, resume their power. Quoting biblical examples, Rutherford regards rulers appointed by the people to rule "covenant-wise and conditionally", according to God's law, "and the people resigning their power to him for their safety, and for a peaceable and godly life under him, and not to destroy them and tyrannise over them" (LR, Q 14: 57). This covenant is presupposed in nature and provides the basis for lawful rebellion by the people against unjust government. Furthermore, God had not given power to a ruler to govern absolutely and above the law: "(t)he law, rather than the ruler, hath the power of life and death" (LR, Q 22: 102).

This essay investigates Rutherford's transforming of Reformed political and legal theory by grounding law and government in the covenant of creation and the vast implications emanating from his perspectives on covenantal natural law and political power in a system of democratic governance. Because the magisterial Reformers did not deviate seriously from the medieval conceptions of natural law and its location in the

All references to Rutherford's Lex, Rex, quote the abbreviated title, the question considered and the page number. human mind, it is necessary to consider the medieval legacy on natural law and conscience in order to appreciate Rutherford's transformative involvement in Reformed politics and legal theory and his lasting contributions to Reformed thought on democratic governance.

\section{THE MEDIEVAL TRADITION OF NATURAL LAW}

\subsection{Natural law and conscience in medieval philosophy}

\subsubsection{The obligating nature of natural law}

Medieval theories of natural law were mostly in agreement that natural law is embedded in the deeper recesses of the human constitution, that it forms an essential part of being human and that it is impressed in human beings by nature. According to St. Augustine the eternal law of God is impressed upon the human essence (the heart), as the image of a ring passes into the wax "without abandoning the ring" (DT, 14, 15). ${ }^{2}$ This passage identifies natural law with eternal law, the former being simply a participation of the latter. The fundamental norm of human actions is present in human beings by the communication of the eternal law. The eternal law, or the reason of God, is the eternal plan of divine wisdom by which the whole creation is ordered, directed and steered towards its final goal. St. Thomas, in his Summa Theologica (1997), clearly states that natural law is not different from the eternal law but rather a participation in that law (ST, P(I-II), Q(91), A(2)). ${ }^{3}$ Therefore natural law is not some instinct or feeling as some passages might indicate. Only human beings (as opposed to animals) share intellectually and rationally in the eternal mind, which explains why only rational creatures have law and the ability to know law (ST, P(I-II), Q(91), A(2)).

According to Thomistic philosophy, natural law directs the activities of human beings by means of certain general precepts (or principles), the most fundamental of which is that good is to be done and evil avoided. The voice of reason makes it possible for human beings to distinguish between morally good and bad actions. Those things for which man has a natural inclination are good and must be regarded as constituting natural law. Firstly, there is the natural human instinct of self-preservation of which the law must take cognisance. Secondly, there is the attraction between the sexes and the desire to conceive, to rear and educate children. Thirdly, human beings have a natural desire to know the truth about God, an inclination that drives humans to shun ignorance. Fourthly, man is inclined to live in society, and it is therefore natural for humans to avoid harming those among whom he has to live. Although these basic precepts, or principles, of natural law are considered immutable, Thomas admits the possibility of changing the secondary precepts, in the form of detailed conclusions derived from the

\footnotetext{
$2 \quad$ References to St. Augustine's De Trinitate, are abbreviated as DT, and the book and chapter cited.
} "The natural law is simply the rational creature's participation in the
eternal law." 
basic precepts, under certain circumstances. To Thomas there is in every human being a natural inclination to act according to reason (or virtuously). This implies that irrational, antisocial, and criminal acts are to be regarded as deviations from human nature, just as the innate instinct of self-preservation may in some people be blotted out by an urge to destroy one's own life.

The supreme moral law inserted in human beings by nature, is the light of reason. Referring to the passage of the Psalmist in Psalm 4, Thomas adds that the light of natural reason, by which we distinguish good from evil, and which belongs to natural law, is simply the impression of divine light in us (cf. ST, $\mathrm{P}(\mathrm{I}-\mathrm{II}), \mathrm{Q}(91), \mathrm{A}(2))$. The light of reason is truth. St. Augustine, after asking how the wicked see the moral rules which even they use to reprove evil actions, replies in the book of the light called truth which describes every law $(D T, 14,15)$. This truth is described by St. Jerome (c. 340-420) as a "natural holiness" impressed on the human soul by God; it resides in the highest part of the spirit, where it judges between what is right and what is wayward (Rosmini, 1989: 10). The fundamental principle of truth placed in the human mind is described by St. Ivo of Chartres as the idea of what is right placed in the human mind by God, the first truth. Through this idea each human being, having only synteresis, differentiates between what is just and what is unjust without any teacher, written law or judge; with this light God enlightens everyone coming into the world (Rosmini, 1989(a): 10). The light of reason is united with the human subject and comes to form part of human nature in such a way that without it humanity would no longer exist.

Can natural law, emanating from human nature, impose true obligations on human beings? Traditional Thomistic views on natural law responded positively to this question. Although natural law is not promulgated with external signs and writing, it is promulgated through the internal light of reason. The obligating force of natural law does not come from reason as a human faculty, but from the light inherent in reason by nature; a light which takes the form of principles as a result of its various applications. Natural law receives its obligating force from being divinely impressed on human nature. Therefore it obliges without the addition of any other particular light it obliges because truth, the law from the hand of God Himself, is written into natural reason. God has impressed in human beings the moral rules of life which together form the natural law; the natural law obliges us because of its relationship with divine nature. Human dictates, therefore, have no force without a relationship with the light impressed on us by God. Without this light, they are obscure, ambiguous and fallible. St. Thomas' theory of natural law therefore leaves us with the following conclusions about the obligating nature of natural law: 1. Natural law obliges per se without the addition of any special light to the light already impressed in human rational nature by God. 2. This law is clear in its principal points, and is proposed to human reason. 3. Human beings have a true moral obligation in the evident points of natural law. 4. In a state of pure nature, free from sin, human beings would have known natural law fully and certainly in all its consequences.

\subsubsection{Medieval conceptions of synteresis as the seat of natural law principles}

The concept of synteresis surfaced in the writings of the early Church Fathers. St. Hieronymus was the first to reserve the term synteresis for that part of the conscience which protects, maintains and preserves the divine law in the human person. For Hieronymus, synteresis denotes the spark of the conscience remaining in the human being after the Fall; it is the spark of the conscience providing humans with the basic knowledge of what is right and wrong in spite of man's fall into sin.

Hieronymus' theory of synteresis played a constitutive role in shaping early medieval views on man's ability to distinguish between good and evil. It is a natural ability which protects, maintains and preserves the divine law in the human mind. Synteresis is the "spark" of the conscience; it governs the other powers of the soul, and protects and preserves the other soulpowers from erring. Gregory of Nyssa (c. 331-395) followed Hieronymus' views that the synteresis is the apex of the human conscience revealing the distinction between good and evil in the human mind. Albertus Magnus (1193-1280) also followed Hieronymus' views of synteresis as the seeds (or remnants) of man's original ability to distinguish between good and evil (a view supported by Maximus Confessor and St. Augustine) (Sum. Th., II, 16, 99). Albertus Magnus regarded the synteresis to be the highest moral power (potentia cum habitu completa or voluntas rationalis appetens bonum, dissentiens malo) (Eisler, 1930 III: 200). As such it is an ability (power) which culminates in the habitus (disposition). It is the spark of reason murmuring against evil, inclining man to the good and testifying against evil; it is a light inclining man to do good (Sum. Th., II, 25, 2-3).

St. Basil (c. 329-379) describes synteresis as the natural judgement (naturae iudicatorum) in which the demands of the natural law (lex naturalis) are inscribed (cf. Sum. Th., II, 25, 2). Synteresis is the natural ability to measure human behaviour to the standards of the lex naturalis.

Tertullian (c. 160-230) describes synteresis as the remnants of the good in all human beings. This ability is essentially the natural inclination to distinguish between good and evil, the seeds of which remain in the human mind (DA, 41). Tertullian's views were followed by Maximus Confessor and St. Augustine (cf. Sum. Th., II, 16, 99).

In Alexander of Hales' views on conscience a distinction is drawn between synteresis and conscience. Synteresis is reserved for the unchanging (immutable) rational spirit in the human person (the spiritus rationalis hominis in an ethical sense) or the light illuminating human reason. To Alexander of Hales, synteresis is the spark of the conscience still operative in the human mind, whilst conscience is the changing (mutable) part (Stoker, 1925: 26-28). In medieval ethical theory, man's natural awareness of moral law became associated with synteresis, the scintilla conscientiae (or spark of the mind), which reminds the human person of the precepts of the moral law (Stoker, 1925: 26-28). 
Although the Medievalists were generally in agreement on the synteresis as the natural ability to distinguish between good and evil and to know the contents of the natural law precepts, theories on synteresis culminated in two distinct philosophical approaches: the respective views of Albertus Magnus and Thomas Aquinas. Albertus Magnus followed Hieronymus' description of synteresis: it is the highest moral power in the form of a potential; it is the spark of reason inclining towards the good and testifying against evil. Synteresis is the enduring inclination towards the good and functions as a "light" in the human mind.

Different from Albertus Magnus, Thomas Aquinas regarded the synteresis not as a potential but as a habitus, the conscience being an actus. Synteresis is the law of the intellect containing precepts of natural law; it moves humans to do good and to shun evil. Different from Hieronymus, Thomas regards synteresis as not functioning beyond the other powers of the soul; it is the total of moral judgments underlying and implanted naturally in the conscience; it affirms the good and shuns evil. To Aquinas, synteresis denotes the law in the human intellect, the precepts of which form the tenets of the lex naturalis. In distinction from synteresis, the basic or original conscience, conscientia implies the relation of knowledge to something - conscience witnesses, binds, incites, accuses, torments, or rebukes (ST, $(\mathrm{P}(1) \mathrm{Q}(79) \mathrm{A}(13))$. Therefore, conscience is not a power but a specific function, namely the application of knowledge (ST, $\mathrm{P}(1) \mathrm{Q}(79) \mathrm{A}(13))$. Conscience, by implication, has the function of practical reason $(S T, \mathrm{P}(1) \mathrm{Q}(79) \mathrm{A}(13) \mathrm{RO}(1)-(2))$. Conscientia can therefore be described as that which controls the spirit and guides the soul as a dictate of reason (ST, $\mathrm{P}(1) \mathrm{Q}(79)$ $\mathrm{A}(13) \mathrm{RO}(1))$. It means, in effect, that conscientia is the dictate of reason, it incorporates a goal-oriented system of knowledge, and it is an act of practical reason in the form of affirmative or negative judgments (ST, (P1) Q(79) A(13)).

The Scholastic views on the nature and role of synteresis (in distinction from conscientia) can be summarised as follows: synteresis is the spark of the intellect, it is the consciousness of the moral law, faintly reminding the human person of good and evil; it is the spark of the conscience, the primary conscience sometimes called the scintilla conscientiae, which manifests itself as a faint murmuring by revealing the precepts of the moral law to the human mind.

\section{THE MAGISTERIAL REFORMERS ON THE NATURAL ABILITY TO KNOW THE NATURAL LAW}

\subsection{John Calvin on natural law and moral knowledge}

Calvin's views on the human conscience, as the seat of natural law precepts, are reflective of most of the views of the magisterial Reformers - particularly Luther ${ }^{4}$ - in their

$4 \quad$ The following abbreviations are used, together with the relevant Scriptural citation where applicable, for citing Luther's individual works in the American edition (Luther, 1958-1967): Sermons on the Gospel of St. John (SJ); Temporal authority: to what extent it should be following of the classical Thomistic approach to the gleaning of knowledge of natural law principles. In most respects Calvin followed Luther's thoughts on natural law, conscience and the human ability to know the basic precepts of natural law: the ethical norms of human behaviour come to expression in the human conscience (WA, 8, 606); the divine moral law is a more complete expression of the precepts of natural law (WA, 24, 9 \& 16, 431); man's fall into sin did not extinguish the "sparks" of reason inherent in the human mind (WA, 10(1), 203); God originally provided man with outstanding abilities as natural endowments (WA, 51(2), 242ff.).

In Calvin's works he uses the concepts ius naturae and lex naturae interchangeably to denote the concept of natural law. To Calvin the lex naturae is the total of practical and ethical principles in human nature containing the basic conceptions of justice and rightness (Op., 49, 37ff.). Similar to other magisterial Reformers Calvin teaches that all human beings - including the Pagans - have knowledge of the basic tenets of natural law $(O p ., 49,37)$. Following the Stoic conceptions of natural law, Calvin maintains that the source of the natural moral law is not cosmic nature or the natural order, but human nature (the heart or human intellect) $(O p ., 47,37)$. Calvin follows the ancient Christian tradition that God had provided human nature with the basic knowledge of right and wrong and that man has an innate sense of justice and fairness. These fundamental concepts of morality and truth are manifested in the human intellect. In fact, human beings are equipped with the ability to know the basic principles of natural law, the seat of which is the conscience or ratio naturalis (Gaius, Institutes, I, I, I, 89). Calvin prefers the Pauline term "conscience" for the sense of the divine judgment, the inner testimony in the human mind, the remnants of the natural ability to discern good from evil (Op., 2, 196). The human knowledge of these moral precepts manifests itself as seeds (or sperms) of justice implanted in the human spirit (Op., 49, 38).

Calvin also applies the term sensus naturae - man's practical perception - to describe the inner human sense of justice and order; the sense of moral and aesthetical values from which emanates moral judgements in the form of the human legal consciousness. Man's sensus naturae is stirred when the social order is threatened, man's inner sense of right affronted, public respectability upset or the value of humaneness negated. The human legal intuition should, however, not be confused with the instinctive animalistic sense shared by animals.

\subsection{Reformed views on the obligating nature of natural law}

The natural law teachings of the magisterial Reformers were by and large in agreement with the Thomistic approach to natural law and its obligating authority. John McNeill observes that the subject of natural law was not a source of controversy between the Scholastic tradition and the Reformers (McNeill, 1946:168-182; also 1941:211-227). Neither does there seem to be a difference in opinion between the Scholastic views

obeyed (TO). References to WA are to the standard edition of Luther's Werke (1883-1987). 
on the one hand and Luther's and Calvin's views on the other regarding a natural law theory grounded in divine providence, in terms of which man's deep intellect (heart or conscience) reflects the fundamental moral principles (albeit dimmed by sin) providing human beings with the potential to be drawn into the pattern of God's wisdom and thereby making them collaborators to establish justice in the world (Raath, 2007:420). To both Luther and Calvin, man's innermost being contains "remnants" or "sparks" of divine justice. In his commentary on St. Paul's epistle to the Romans, Luther teaches that natural law is inscribed in the hearts of human beings by the Holy Spirit. Natural law is nothing but the divine law instilled in man's heart as a result of God's creational work and divine righteousness (Raath, 2007: 41). God's righteousness, reflected in the precepts of natural law, serves the purpose of ensuring that the world may be stable and that an orderly and peaceful life may be ensured and justice be preserved (LW, 13:369 (LP) Psalm 112)). To Luther natural law is, in principle, accessible to reason (LW, 45:129 (TO)), and because of the central function of man's reason in gaining knowledge of natural law, even the Gentiles have a rational knowledge of the precepts of natural law (LW, 22:150 (SJ), John 1). Through the Holy Spirit, man's rudimentary knowledge of natural law is enlightened (LW 46:242 (SCS); WA 11:280 (Predigten und Schriften, 1523); 17(2):91 (Fastenpostille, 1525); 30(2):562 (Schriften, 1529/30)).

John Calvin also discursed extensively on the nature and functions of natural law (Schreiner, 2001:77). In his Institutes, Calvin alludes to natural law as the "inward law" (lex illa interior) engraved (impressam) "upon the hearts of all", and in his comments on Romans 2:14-15, he states that the Gentiles also, "beyond doubt" have certain conceptions of justice and rectitude which are naturally inborn (naturalites ingenita) in the minds of men (Schreiner, 2001:77).

The Swiss Reformer Heinrich Bullinger's conception of natural law is typical of the Reformed natural law theories of the sixteenth century. In his Decades (1549 [2004]) Bullinger describes the law of nature as the instruction of the conscience, and, as it were, a certain direction placed by God Himself in the minds and hearts of men, to teach them what they have to do and what to eschew (Bullinger, 2004: II, I, 194). The law of nature is not called the law of nature, because in the nature and disposition of man there is of or by itself that reason of light exhorting to the best things, "and that holy working"; "but for because God hath imprinted or engraven in our minds some knowledge, and certain general principles of religion, justice, and goodness, which because they be grafted in us and born together with us, do hereby seem to be naturally in us" (Bullinger, 2004: II, I, 194).

With reliance on Romans 2: 14-16 Bullinger, in line with the medieval natural law theorists, argues that even the Gentiles have the law by nature, for they have in themselves the law of nature, the knowledge of which is imprinted by God in their nature, so that they may understand what is good and what is evil, what is to be desired and what is to be shunned. By these words of the apostle we do understand that the law of nature is set against the written law of God (Bullinger, 2004: II, I, 195). The origin of the law of nature is not the corrupt disposition of mankind, but of God Himself, "who with his finger writeth in our hearts, fasteneth in our nature, and planteth in us a rule to know justice, equity, and goodness" (Bullinger, 2004: II, I, 195). The law of nature - as a reflection of the divine moral lawinstructs the conscience, and either accuses and condemns the evil committed or absolves and acquits, if nothing is committed contrary to the law: "because this conscience only and alone is instead of a thousand witnesses" (Bullinger, II, I, 195).

The tenets of natural law are twofold: firstly, acknowledge God and worship Him; secondly, keep and maintain society and friendship among men. The first teaches that there is a God Who is to be acknowledged and reverently worshipped; the second entails that whatsoever we would that humans should do to us, we should also do to them, or: live honestly, do not hurt others, give every man his own; provide things necessary for life, and keep it from distress (Bullinger, 2004: II, I, 196-197).

Although natural law obliges on its own because of its authority as the light of reason, the consent, the will, and ability to fulfil the law must of necessity be given of God. Therefore, nature without grace is of no effect because the law of nature is not grafted in man by God with the intention that it should work man's salvation without grace and Christ; natural law teaches us what is good and what is evil to convince us of our sins and to place us without excuse before God (Bullinger, 2004: 206).

\subsection{Natural law and the covenant of creation in sixteenth-century Reformed thought}

Reformed theology of the sixteenth century experienced an upsurge in applications of the doctrine of the covenant. Covenantal views of first-generation reformers, among whom Heinrich Bullinger (1504-1575) was the most prominent and well-known in England, applied the idea of the covenant to both theological and political issues. In addition to distinguishing covenants of works and grace, Palatinate, English and Scottish theologians in the second half of the sixteenth century referred to a creation covenant established by God with creation (Visser, 1996: 444). Although it is difficult to trace the origin of the term in the writings of the late sixteenth century, by the end of the century it had become a commonplace in Reformed theology (Visser, 1996: 442-445). Prominent Reformed theologians including Caspar Oleveanus (1536-1587), Zachary Ursinus (1534-1587), William Ames (1576-1633), Robert Rollock (1555-1599), John Cameron (1579-1625), John Ball (1585-1640), Francis Turretin (1623-1687) and Edward Leigh (1602-1671) apply the term in their theological writings.

William Ames (1576-1633), a student of William Perkins (1558-1602), in his Medulla Theologica (1623), teaches a covenant of works with Adam. To this he adds a positive command to the law of nature, involving a promise of continuing of animal life, a later "exaltation to spiritual life" and a threat of bodily death. Ames describes this as the law of God or His covenant with man in creation: "Do this and you will live; if you do not you shall die" (1983: 113). Since man is less perfect than the angels and needs more instruction and practice, something positive was added to the law of nature. Because man in his animal life understands 
by the senses and is led by the hand, as it were, from sensible to intelligible and spiritual things, outward symbols and sacraments were added to the spiritual law to illustrate and confirm it. These symbols contained a special and positive law, a profession of general obedience to the law of nature put in man before, and a solemn confirmation of promises and threats as sanctions (1983: 112-113).

In Britain Robert Rollock (1555-1599), in his Tractatus de vocatione efficai (1597) distinguishes a pre-lapsarian covenant with Adam. He grounds the covenant of works (which may be called legal or natural) in nature, which was pure and holy, and in the law of God, which was in the first creation engraved in man's heart (Rollock, 1603: 6-7). After God had created man after His own image, pure and holy, and had written His law in his mind, He concluded a covenant with man. The terms of this covenant were that God promised man eternal life upon the condition of good and holy works which should correspond to the holiness and goodness of their creation and conform to His law. God concluded this covenant of works amicably with man, for in the creation man was God's friend and not his enemy. "The thing promised in the covenant is life eternal, first, not righteousness: for that man in creation was even then just and perfect" (Rollock, 1603: 7). To the question of whether in the first creation good works in the covenant of works were required of man as meritorious for the promised life, he answers that they were not. Good works were due in creation as pledges of thankfulness in man to his creator, to glorify God. Rollock adds that although the covenant of works is abolished, and of no effect regarding justification and salvation, the moral law remains as a rule of life for the believer: "So then the law has ceased, as it was the rule of the works of nature required in the covenant of grace: but it is still in use to them which are in Christ, as it is the rule of the works of grace" (Rollock, 1603: 10).

Edward Leigh (1602-1671), in his work A treatise of Divine promises (1633), distinguishes a legal and an evangelical covenant. The former he calls a covenant of nature and a covenant of works. Leigh teaches that the foundation of the covenant of nature is the creation of man and the integrity of human nature (Leigh, 1633: 68). The two sacraments of this covenant were the Tree of Knowledge, respecting the Law, do this, and the Tree of Life respecting the promise, Live (Leigh, 1633: 64).

Caspar Oleveanus (1536-1587) gives the clearest expression of the covenant of nature. In his De substantia he emphasises human responsibility under the covenant of creation. In Oleveanus' covenant theology, human conscience and the relationship in Paradise between God and humanity find their culmination in the covenant of creation (cf. Ward, 2003: 54). The foedus creationis appears to be a foedus natural because it was a relationship in which Adam and Eve by nature were bearers of the divine image and conformed to their Creator (Bierma, 1996: 114). ${ }^{5}$ This covenantal relationship carries responsibilities for man. God had revealed Himself to Adam in His image and in His handiwork. In return God expects man to pledge to Him full allegiance, honour and glory (Olevianus, 1585: 251). Adam received God's favour through the divine image with the gifts of knowledge, righteousness and holiness - all on condition of obedience (Olevianus, 1585: 79, 80). The foedus creationis is a ius creationis, entailing an obligation to the Creator by man as creature (Olevianus, 1578(a): 75-76). The relationship of human conformity and obligation to God is witnessed by the law of nature (or natural law) (lex naturae, ius naturae, vox naturae, ius divinum, ius De natural), that is His holy will implanted in human nature, written in the heart of man, and inscribed in the human mind (Olevianus, 1585: 151). God's natural knowledge was manifested as a natural knowledge (notitia) of God concerning divine holiness and hatred of sin (Olevianus, 1578(b): 64-65). At creation the law of nature manifested itself in the divine image; as an expression of God's will, it was an expression of His righteousness and holiness represented in His image. Conformity to God's image, was also conformity to His will (Olevianus, 1585: 207).

The lex naturae is located in the human conscience as the place in which the law of nature holds its court (Graafland, 1994: 51-52; Bierma, 1996: 115). The conscience (as the notitia Dei) impels humans to the good and judges that which is wicked (Bierma, 1996: 116). The law of nature testifies to our obligation in and by the ius creationis, although it is not the covenant relationship itself (Bierma, 1996: 116). In the Fall of mankind the covenant of creation between God and man was destroyed, accompanied by a loss of the divine image in man. However, man's debt to God was not cancelled (Olevianus, 1585: 251). By the ius creationis (the law of creation) man, as a sinner, is still bound to obey God. Through the Fall, the law of nature in the human constitution was weakened, but not completely erased. Sparks of the knowledge of God remain. Man's naturalis sensus in the human conscience still teaches that God hates sin and will exact punishment for it. Only through Christ's atonement can the clamour of the law in the conscience be silenced (Olevianus, 1585: 195-196, 298, 269-270).

\section{COVENANT, CONSCIENCE AND NATURAL LAW IN SAMUEL RUTHERFORD'S LEX, REX}

\subsection{Covenant and nature in Rutherford's theology}

In his Covenant of life opened, or, a treatise of the covenant of grace (1655), Rutherford describes the law and covenant of works as a rule of everlasting righteousness, containing precepts of the law of nature that are intrinsically good, such as to know, love, fear, and trust in him as the only true God: "and in this sense it is an eternall Covenant" (Rutherford, 1655: 214). These are the same principles inscribed originally upon the heart of Adam at his creation, now distorted and dim because of sin, yet still present to some extent within all human beings (Marshall, 1995: 17). However, all human beings are sufficiently enlightened to know God and obey the law of creation. Rutherford equates the law of creation with the moral law, as the embodiment of the covenant of creation. The conscience is the treasure house containing the principles of natural law: "Of this intellectual Treasure-house, wee are to know these. That in the inner Cabinet, the naturall habit of Morall principles lodgeth, the Register of the common 
notions left in us by nature, the Ancient Records and Chronicles which were in Adam's time, the Law of Nature of two volumes, one of the first Table, that there is a God, that he createth and governeth all things, that there is but one God, infinitely good, most just rewarding the Evill and the good; and of the second Table, as to love Parents, obey Superiours, to hurt no man, the acts of humanity; All these are written in the soule, in deep letters, yet the Inke is dimme and old, and therefore this light is like the Moone swimming through watery clouds, often under a shadow, and yet still in the firmament. Caligula, and others, under a cloud, denyed there was any God, yet when the cloud was over, the light broke out of prison, and granted, a God there must be; strong winds doe blow out a Torch in the night, and will blow in the same light againe" (Rutherford, 1649: 7).

Rutherford's deliberate attempt to understand the whole of nature and all ethical laws from the perspective of the Biblical doctrine of the covenant and to apply them to the political life in the state must be regarded as a unique contribution to the Reformed theory of law and politics. God's covenant with nature involves a legal principle by which the whole of creation tends to obey God. In human nature these principles are manifested as precepts of the Decalogue engraved on the heart of man simultaneously with his creation before they were announced by Moses. These precepts constitute the law of nature, the original covenant of creation. Because of man's total depravity as a consequence of the Fall, the law of God can only be recognised through the working of the Holy Spirit (Rutherford, 1655: 19).

In Rutherford's Lex, Rex, the covenant of creation becomes a powerful paradigm for explaining God's providential government of creation to bring the elect to salvation and to improve man's temporal existence in society. Essentially, the law of nature is an instrument in God's providential government of the world to preserve the human race. All living creatures - man in particular - have the natural inclination to preserve themselves, therefore the law of nature could be reduced to the law of self-preservation (Marshall, 1995: 263). For the proper understanding of nature, the divine authority of Scripture is required - grace does not destroy nature but perfects it. The close bond between, on the one hand, covenant and nature and, on the other, divine and natural law, brings Rutherford within the context of the natural law theories of the magisterial Reformers, notably Bullinger's perspectives that the law of nature is not the written law but the law grafted in man; to teach and direct man, to distinguish between good and evil; it is from God himself, who with his finger writes in our hearts, fastens in our nature, and plants in us a rule to know justice, equity, and goodness (Bullinger, 2004: II, I: 195; Marshall, 1995: 264).

By viewing natural law from a covenantal perspective, Rutherford underscores the insufficiency of natural law as an independent source of moral norms, isolated from scripture. Although nature reveals the law of God, it is insufficient as an autonomous source of ethical truths. Because of human rebellion and breaking the covenant of nature, natural law needs Scripture to adequately understand God's will for mankind (Marshall, 1995: 265). Marshall comments as follows upon man's natural awareness of the precepts of the Decalogue as a covenant-consciousness: "Rutherford could speak of the existence of natural law because, for him, all of nature was revelatory of God's covenant-making character, and thus of his ethical will. For him, all of nature revealed the reality of God, and God revealed himself in all of nature. Therefore he could appeal to nature within the covenant framework because he knew it would resonate as truth in every heart" (Marshall, 1995: 266).

\subsection{The political implications of Rutherford's views on the covenant of nature and natural law}

\subsubsection{Primary and secondary causation}

The creational bond between God and the whole human race impacts strongly on the political duties of rulers and subjects in the commonwealth. This bond takes the form of a covenant regulating their relationship by the law of God. Due to the political covenant under the law of God (divine and natural), it is contrary to the Word of God for a king to hold absolute power and thus have freedom to be a tyrant and destroyer of his people (LR, Q 14: 54-62). Rutherford's covenantal view of human beings and nature has important consequences. Not only does he explain man's knowledge of natural law principles from this paradigm but also man's ability to recognise fundamental covenantal principles for life in civil society. When God created Adam He engraved the law of the image of God, the natural knowledge of God, His holiness, justice, mercy, and knowledge of right and wrong, and a natural holiness and innate conformity of the heart to the eternal divine law in the human soul (Rutherford, 1659: 139). This is the natural law, the law of the image of God accompanying the covenant of creation (Rutherford, 1655: 214). In addition man was empowered to recognise covenant principles for life in society; among them being the deeply embedded recognition that there is a mutual obligation to live in society - an obligation that involves the need of government. This "covenant natural" precedes the "covenant politic (civil)" (Rutherford, 1659: 26; LR, Q 14: 54-62).

The implications of the civil (or political) covenant for political life in the commonwealth are profound. For purposes of this essay two important consequences are briefly discussed: human agency is the providential means of God designed for political life in society and the limits to the powers of rulers emanating from nature. Human agency and the role of secondary causation form an important part of Rutherford's discourse on divine providence and human responsibility in society. Liberty and safety constitute two fundamental natural law principles. Because liberty is natural to all people it cannot be totally surrendered to rulers. Rutherford emphasises that rulers do not receive their authority directly from God, as some Old Testamentary examples show. In later times God works through means and instruments and provides human beings in society with an instinct of reason to appoint rulers over themselves (LR, Q 3: 3, 4, 5; Q 4: 6; Q 5: 12). Political authority, therefore, comes only "mediately" from God, proceeding from God by the mediation of the consent of a community, which transfers their power to one or more rulers ( $L R, Q$ 2: 2; $Q$ 22: 
99-106). ${ }^{6}$ Sovereign power is always held as a sort of power in trust, loaned to a ruler, who acts as "a life-renter, not a lord, or proprietor of his kingdom" (LR, Q 19: 86). Furthermore the true purpose of government revealed by God in Scripture and through the laws of nature and human reason is also opposed to absolute power wielded by political rulers. Citing St. Paul, $1^{\text {st }}$ Timothy 2:2, Rutherford holds that God's purpose in instituting civil laws and government is to ensure the external peace, honesty, quiet life and godliness of His church and people. God, the omniscient and omnipotent source of all power, has appointed sufficient means for this divine objective, but no sufficient means could exist if one man were to have an absolute unlimited power to subordinate justice to his own arbitrary will, creating a state of insecurity and confusion (LR, Q 19: 87).

\subsubsection{Limitations to the ruler's powers}

The natural law principle salus populi suprema lex has an important bearing upon the principle of the mediate ordination of rulers by the people's consent (LR, Q 25: 119-125). Since the people are, under God, the first author of both the fundamental laws of the country and of the monarchy, their safety is the principal end which must be sought (LR, Q 25: 119). This end will be better accomplished by the ruler through limited powers aided by subordinate magistrates than with absolute power put into his hands. Because of human sinfulness, the possession of exorbitant powers has an intoxicating influence liable to abuse (LR, Q14: 54-62). The safety of the people serves as a fundamental legal axiom which limits all human laws in both content and execution (application) (Webb, 1964: 98). Because rulers are rulers according to the law, and not as rulers of the law, they do not have the power to interpret and apply the laws of the commonwealth as they please. Rutherford cites the biblical example of King Saul's "exponing the law after a tyrannical way, against the intent of the law, which is the diamond and pearl of all laws - the safety of the innocent people, was justly resisted by the innocent people, who violently hindered innocent Jonathan to be killed" (LR, Q 27: 137). The royalist assumption that absolute power is acceptable is precluded because it is against nature for the people to have, and give away, a power to destroy themselves either physically or spiritually. Because rulers are bound to the duty to be loving fathers, guides and protectors of the people, they cannot act as bloody conquerors whose actions are a denial of all the good qualities which ought to be found in a ruler. Even if a conqueror were to force a defeated people to submit to his rule, he could not thereby become a lawful monarch. Consent given under extremes is not valid and people, or their posterity, are entitled to vindicate their own liberty given away unjustly. Although evil and unjust causes might appear to triumph for a time, this is no indication of God's approval (LR, Q 10: 39-45).

Rutherford emphasises that a community is entitled to resume the power conferred on its ruler. A community in itself, even without rulers, is still a body politic (or civil society) because it has the ability to constitute or consent to government (LR, Q 7: 22-28). In terms of Romans 13, abused power cannot be regarded powers ought to be obeyed (1558). as God's ordinance. Rutherford draws a distinction between the power of the ruler personally and the lawful power vested in his office. Although subjection to political authority is required by the fifth commandment and by Romans 13, these texts do not disallow resistance to an individual king who sinfully exceeds or abuses his royal authority. Quoting Knox's History of the Reformation in Scotland as authority, Rutherford distinguishes between the authority which is God's ordinance, and the person placed in authority as a human being, sinful, fallible and liable to offend (LR, Q 29: 146). Since self-preservation is an individual's natural right, it is surely natural to the nation also. Therefore, the English and Scottish parliaments were entitled to resist the king's personal will. Rutherford quotes Henry Parker's Observations upon some of his Majesties late answers and expresses (1642) in support of the king not serving as a father to the community but rather acting as a "son to them, and they his maker" (LR, Q 25: 123). Although the king had executive power over his people, he was still their inferior, since they had the "fountain power" which made him king. The people gave the king a political power for their own safety but retained a natural power of self-preservation. In tyrannical acts inconsistent with the fiduciary trust placed in him he was accountable to the parliament which represented the people (LR, Q 19: 77-88).

\subsubsection{The impact of Rutherford's natural law covenantalism on Puritan political theory}

Rutherford's expounding of the covenantal natural law foundations of political society found support in a number of influential Puritan political works. James Stewart of Goodtrees (1635-1713), a future Lord Advocate of Scotland, found support in Rutherford's Lex, Rex, for justifying the Pentland Rising of 1666. Stewart adapted Rutherford's ideas to the circumstances of Restoration Scotland by allowing resistance by the people without the sanction of Parliament. Stewart asked why a considerable part of the nation should not defend their lives, estates, liberties and religion against sanguinary soldiers, when all legal means of redress had been denied them (cf. Maltzahn, 1998: 232-234). From the angle of the individual's right of self-defence, the people's right was vindicated when all doors of hope were closed and, moreover, the whole community was bound by solemn vows and covenants (Stewart, 1669: 14-15, 23-27).

With copious references to Lex, Rex, Stewart maintains that prior to any government each man governed his own affairs in the state of nature, "having no other law to square his actions by, than the moral law, or the law of nature". In this condition nobody had more right than anyone else to exercise civil authority. Although parents had authority over children, husbands over wives, and masters over servants, these forms of dominion entitled no one to political authority. Arguing from the principle of self-preservation, Stewart remarks that if it were assumed that people acted rationally at the setting up of rulers, it could never be claimed that they surrendered their right of self-defence, particularly in circumstances where rulers acted as open enemies. Because the right of self-defence is natural and inalienable, the transfer of political power from the people was to designate the person, persons, or dynasty to rule, in the form of government chosen by the people 
(Stewart, 1669: 80-91). Because the ruler's power is merely a fiduciary power, such as the power of a tutor or patron "created of the people that he might defend them from injuries and oppressions ... he hath no more power than of a Tutor, publick servant, or Watchman" (Stewart, 1669: 147-149).

Stewart traces the origin of the relationship between ruler and people to a real compact, either explicit or implicit, that a particular person be appointed as sovereign. In addition there must be some conditions upon which this mutual compact is based, for a compact cannot be without conditions (Stewart, 1669: 96-98). If the king neglects, or exceeds, his duty, the people have a right to redress, which exists in all mutual compacts. By virtue of the mutual compact, the people have a right in law to pursue him for performance (Stewart, 1669: $112,115-117,150-152)$. Stewart follows Rutherford in maintaining that the Scottish monarchy had been founded by consent, not conquest as alleged in James VI and James I's The trew law of free monarchies (Stewart, 1669: 92-94, 119-124, 144-146).

In Naphtali (1667), a work co-authored by James Sterling, and also relying on Lex, Rex, Stewart voices the principle that whatever form of government is set up by the people under God, the people remain ultimately superior to the supreme power (Stewart \& Stirling, 1667: 118). When government is "manifestly and notoriously" perverted people may enter into new societies for their defence and preservation (Stewart \& Stirling, 1667: 177-181). In $x$ it is stated that "as all Societies, Governments, and Lawes are appointed in due Subordination to God and His superior Will and Law, for His Glory and the Common Good of the People, including the safety of every individual" (Stewart \& Stirling, 1667: 240); so, "if either this Subordination be notoriously infringed, or these Ends intolerably perverted, the common tie of both Society, Government and Law, is so far dissolved. Hence is it that a King or Rulers commanding things directly contrary to the Law of God, may be, and have been justly disobeyed, and by fury or folly destroying or alienating the Kingdome, may be and have been lawfully resisted" (Stewart \& Stirling, 1667: 240). The authors continue: "That through the manifest and notorious Perversion of the great Ends of Society and Government, the Bond thereof being dissolved, the persons, one or more thus liberated therefore, do relapse into their primeve Liberty and Priviledge, and accordingly as the similitude of their case and exigence of their cause doth require, may upon the very same principles again join and associate for their better Defence and Preservation, as they did at first enter into Societies" (Stewart \& Stirling, 1667: 242-243).

Alexander Shield's (1660-1700) A hind let loose, based on ideas of Knox, Buchanan and Rutherford, published in 1687, maintains that the moral power is lawful authority; it is the power ordained of God as described in Romans 13, and conveyed by the people to king and parliament. Government is from God, but He does not determine by any special revelation who the rulers in a specific commonwealth shall be. God therefore makes provision for political authority by mediation of human beings, giving them rules how they shall proceed in setting up government, and by the law of nature He has enjoined government to be, but has not ordered the particulars of it, because God has committed it to the positive transactions of human beings
(Shields, 1797: 335-338, 364, 328, 303-304, 390). If government is destructive to the ends of the glory of God and the good of mankind, the people are released from their obligation to government. The compact between the ruler and the people is transacted in the ruler's admission to the government, in which the law of God regulates both parties. The ruler's power is a trust for which he is accountable to the people (Shields, 1797: 351-352, 354, 388, 340).

\section{CONCLUSIONS}

Rutherford's covenantal natural law theory marks a distinct shift from the Thomistic natural law view. Rutherford's argument from natural law is based on the obligatory nature of divine law: government is ordained by God and this obliges the citizens of the state to obey. This brings a distinct shift from Aquinas' natural law theory with respect to nature. For Aquinas "natural" entails the state of affairs which usually happens or is expected to happen (Flinn, 1978-1979: 56). Through natural reason man can discover what is expected to happen. Because human beings naturally congregate together to protect themselves by government, Aquinas deduces that it follows that humans ought to do so. However, as Flinn rightly indicates, Aquinas and other natural law theorists err by furthering the "naturalistic fallacy"; just because something is a certain way, does not establish that it should be that way. Flinn observes: "You cannot reason from the is to the ought on rationalistic or autonomous grounds." Rutherford effectively avoids this fallacy by beginning with positive, divine law as revealed in the Scripture. Furthermore he does not draw the conclusion from the natural creation order which is normally drawn by natural law theorists. He argues that civil society is natural only insofar as God has created man a social creature. Civil society, therefore, is natural in its root, but as to its mode (or manner) it is entirely voluntary. Therefore, when men choose to defend themselves by handing power and authority to another that is not natural, for men are not born to live in subjection to each other. Rather, when men devolve power on to a particular official, it is a positive moral action, not a natural one (Flinn, 1978-1979: 57).

Rutherford's Biblical interpretation of the creation covenant and the covenantal natural law distinguishes between the institution of civil government and its form or expression in any particular time. Because God has directly instituted government, and its exercise of justice, it must be governed by God immediately. However, the particular method or form which civil government may take can vary, for here God works through secondary means - that is through the people who are governed. Although forms of government may change, the root and basis of government remain immutable. The people are obliged to obey governments, because they are ordained by God's law. This, according to Rutherford, is the foundation of civil government. But, as to whether citizens should submit to a particular civil government, or whether they should have this man or that to govern them, is another issue. It is here that the conditional consent and choice of the people become important. 


\section{LIST OF REFERENCES}

Ames, W., 1983, Marrow of theology, Labyrinth, Durham, NC.

Aquinas, T., 1997, Summa Theologica, Ages Software, Albany (The Master Christian Library: Books for the Ages).

Augustine, ST., 1997, On the Holy Trinity, in Nicene and Post-Nicene Fathers of the Christian Church (Early Church Fathers), Wm. B. Eerdmans Publishing Company, Grand Rapids, Michigan.

Bierma, L.D., 1996, German Calvinism in the confessional age. The covenant theology of Caspar Olevianus, Baker Book House, Grand Rapids, Michigan.

Bullinger, H., 2004, The decades, vols. 1 \& 2. Reformation Heritage Books, Grand Rapids, Michigan:.

Calvin, J., 2005, Opera, vols. 1-59. H.J. Selderhuis (ed.). Instituut voor Reformatieonderzoek, Apeldoorn.

DA see TERTULLIAN, 1997.

DT see AUGUSTINE, 1997.

CE see HIERONYMUS, 2010

Flinn, R., 1978-1979, 'Samuel Rutherford and Puritan political theory', The Journal for Christian Reconstruction, 5(2): 49-74.

Graafland, C., 1994, Van Calvijn tot Comrie. Oorsprong en ontwikkeling van de leer van het verbond in het Gereformeerde Protestantisme, vols $3 \& 4$, Boekencentrum, Zoetermeer.

Hieronymus, S.T., 2010, Commentarii in Ezechielem, Brepols Publishers, Turnhout.

Leigh, E., 1633, A treatise of the Divine promises, London: n.p.

LR see Rutherford, 1982

Luther, M., 1883-1987, Werke: kritische Gesamptausgabe. 78 vols., Hermann Böhlaus Nachfolger, Weimar.

Luther, M., 1958-1967, Works, American edition. 55 vols. J. Pelikan (vols. 1-30) \& H. Lehmann (vols. 31-55) (eds), Concordia, Philadelphia.

Magnus, A., 1651, Opera, vols. 17 \& 18. P. Jammy (ed.), Lyon.

Maltzahn, N Von., 1998, The Wig Milton. Milton and republicanism, Armitage, D., Himy, A. and Skinner, Q. (eds). Cambridge University Press, Cambridge.

McNeill, J.T., 1941, 'Natural law in the thought of Luther', Church history, 10:211227.

McNeill, J.T., 1946, 'Natural law in the teaching of the Reformers', Journal of religion, 26:168-182.

Olevianus, C., 1578(a), In Epistolam D. Pauli Apostoli ad Galates, Eustathius Vignon, Geneva.

Olevianus, C., 1578(b), In Epistolam D. Pauli Apostoli ad Romanos, Eustathius Vignon, Geneva.

Olevianus, C., 1585, De substantia foederis gratuity inter Deum et electos, Eustathius Vignon, Geneva.

OP see CALVIN. 2005

Raath, A.W.G., 2007, 'Providence, conscience of liberty and benevolence - the implications of Luther's and Calvin's views on natural law for fundamental rights', In die Skriflig, 41(3): 415-442.

Rollock, R., 1603, A treatise of God's effectual calling, T. Man, London.
Rosmini, A., 1989, Conscience, Rosmini House, Durham.

Rosmini, A., 1989(a), Principles of ethics, Rosmini Book House, Durham.

Rutherford, S., 1655, The covenant of life opened, or, a treatise of the covenant of grace, Robert Brown, Edinburgh.

Rutherford, S., 1659, Influences of the life of grace, A. Crooke, London.

Rutherford, S., 1982, Lex, Rex, or the law and the prince, Sprinkle Publications, Harrisburg, Virginia.

Shields, A., 1797, A hind let loose, John Kirk, Glasgow.

Schreiner, S.E., 2001, The theatre of his glory: nature and the natural order in the thought of John Calvin, Baker Book House, Grand Rapids.

Stewart, J. \& Stirling, J., 1667. Naphtali, n.p.

Stewart, J., 1669, Jus populi vindicatum, n.p.

Stoker, H., 1925. Das Gewissen, Verlag von Friedrich Cohen, Bonn.

Sum. Th. see MAGNUS. 1651

Tertullian, 1997, De Anima, in Nicene and Post-Nicene Fathers of the Christian Church (Early Church Fathers), Wm. B. Eerdmans, Grand Rapids, Michigan:

Visser, D., 1996, Covenant. The Oxford Encyclopedia of the Reformation, Vol. I. H.J. Hillerbrand (ed.), Oxford University Press, Oxford.

WA see LUTHER. 1883-1987.

Ward, R.S., 2003, God and Adam. Reformed theology and the creation covenant, New Melbourne Press, Wantirna.

Webb, O.K., 1964, The political thought of Samuel Rutherford, Ph.D. Thesis, Duke University. 